\title{
Pedobacter aquatilis sp. nov., isolated from drinking water, and emended description of the genus Pedobacter
}

\author{
Virginia Gallego, Maria Teresa García and Antonio Ventosa \\ Department of Microbiology and Parasitology, Faculty of Pharmacy, University of Sevilla, \\ 41012 Sevilla, Spain
}

Correspondence

Antonio Ventosa

ventosa@us.es

\begin{abstract}
A Gram-negative, rod-shaped, non-spore-forming bacterium (strain AR107 ${ }^{\top}$ ) was isolated from the drinking water distribution system of Seville (Spain). A polyphasic taxonomic study of the isolate resulted in its identification as a member of the genus Pedobacter. On the basis of $16 \mathrm{~S}$ rRNA gene sequence comparisons, strain AR107 ${ }^{\top}$ was shown to belong to the phylum Bacteroidetes, being related to members of the genus Pedobacter. It showed $95 \cdot 2 \%$ sequence similarity with respect to the type strains of Pedobacter heparinus and Pedobacter piscium, and $94 \cdot 1 \%$ similarity with respect to the type strain of Pedobacter himalayensis. The predominant fatty acids were iso- $\mathrm{C}_{15: 0}$, iso- $\mathrm{C}_{17: 0} 3-\mathrm{OH}$ and summed feature 3 (iso- $\mathrm{C}_{15: 0} 2-\mathrm{OH}$ and/or $\mathrm{C}_{16: 1} \omega 7 \mathrm{c}$ ), which supports the affiliation of strain AR $107^{\top}$ to the genus Pedobacter. The DNA G+C content of this strain was $38 \mathrm{~mol} \%$. On the basis of the phenotypic, phylogenetic and genotypic results, strain AR $107^{\top}$ represents a novel species, for which the name Pedobacter aquatilis sp. nov. is proposed. The type strain is AR $107^{\top}\left(=\right.$ CCM $7347^{\top}=$ CECT $7114^{\top}=$ JCM $\left.13454^{\top}\right)$.
\end{abstract}

The genus Pedobacter belongs to the family Sphingobacteriaceae and currently includes seven species: Pedobacter heparinus (the type species) (Steyn et al., 1998), Pedobacter africanus (Steyn et al., 1998), Pedobacter caeni (Vanparys et al., 2005), Pedobacter cryoconitis (Margesin et al., 2003), Pedobacter himalayensis (Shivaji et al., 2005), Pedobacter piscium (Steyn et al., 1998) and Pedobacter saltans (Steyn et al., 1998). Members of this genus have been isolated from soil, fish, a nitrifying inoculum and glacier samples from the Tyrolean Alps (Austria) and a Himalayan mountain (Steyn et al., 1998; Margesin et al., 2003; Shivaji et al., 2005).

The culturable bacterial population from tap water collected at different points of the distribution system of Seville (Spain) was studied in order to monitor the water quality in microbiological terms. Samples (25 l) of drinking water were concentrated by using a tangential flow filtration system (Filtron) and plated on plate count agar (Difco) and R2A (Difco) (Reasoner \& Geldreich, 1985). Plates were incubated at $28^{\circ} \mathrm{C}$ for 7 days and different morphological colonies were subsequently plated in order to obtain pure cultures. During the sampling campaign of January 2004, strain $\mathrm{AR} 107^{\mathrm{T}}$ was isolated on R2A medium.

The 16S rRNA gene of strain AR $107^{\mathrm{T}}$ was amplified using the universal primers 16F27 and 16R1488, as described previously by Mellado et al. (1995). Sequencing was

The GenBank/EMBL/DDBJ accession number for the 16S rRNA gene sequence of strain AR $107^{\top}$ is $A M 114396$. performed by NBT-Newbiotechnic (Seville, Spain), using an automated DNA sequencer (model 3100; Applied Biosystems). Alignment of the 16S rRNA gene sequence was carried out using the ARB software program (Ludwig et al., 2004). Phylogenetic trees were inferred by using three tree-making algorithms: maximum parsimony (Kluge \& Farris, 1969), neighbour joining (Saitou \& Nei, 1987) and maximum likelihood (Felsenstein, 1991). The almostcomplete $16 \mathrm{~S}$ rRNA gene sequence of strain AR $107^{\mathrm{T}}$ (1450 bp) was compared by using BLAST with sequences of related organisms retrieved from the GenBank/EMBL/ DDBJ databases: the analysis showed that members of the genus Pedobacter were its closest phylogenetic neighbours. The sequence similarity values with respect to the type strains of species of the genus Pedobacter were generally between $94 \cdot 1 \%$ (with the type strain of $P$. himalayensis) and $95 \cdot 2 \%$ (with the type strains of $P$. heparinus and P. piscium), although the 16S rRNA gene sequence similarity with respect to the type strain of $P$. saltans was only $90.0 \%$. The maximum-parsimony phylogenetic tree constructed includes this strain in a separate branch within the genus Pedobacter (Fig. 1). When neighbour-joining and maximum-likelihood algorithms were used, similar phylogenetic trees were obtained (not shown), indicating the congruence of the phylogenetic position obtained for strain AR107 $7^{\mathrm{T}}$. According to the phylogenetic data, the isolate belongs to the genus Pedobacter, but does not show $16 \mathrm{~S}$ rRNA gene sequence similarity values higher than $95 \cdot 2 \%$ with respect to the species of the genus Pedobacter, 


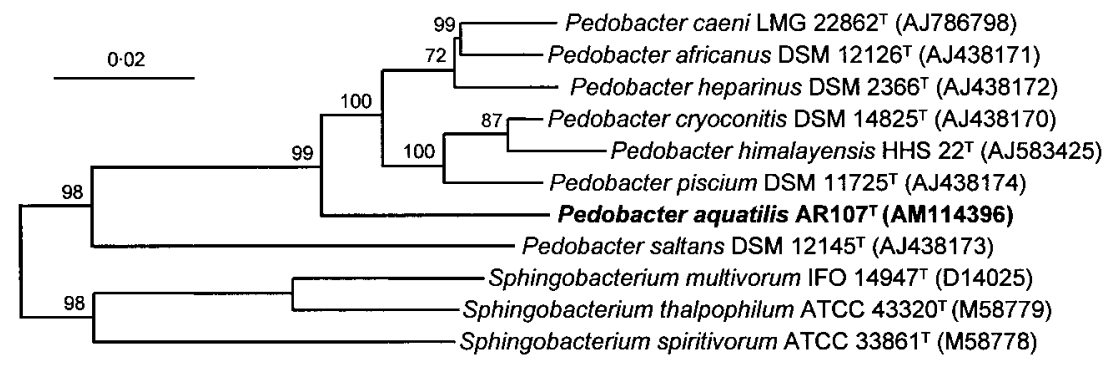

Fig. 1. Maximum-parsimony tree, based on 16S rRNA gene sequence comparisons, showing the position of strain AR $107^{\top}$ and the type strains of Pedobacter and Sphingobacterium species. Bootstrap percentage values higher than $70 \%$ (from 1000 resamplings) are indicated at branching points. GenBank accession numbers are shown in parentheses. Bar, $2 \%$ sequence divergence.

indicating that this strain represents a novel species of this genus (Stackebrandt \& Goebel, 1994).

Chromosomal DNA was isolated and purified according to the method described by Marmur (1961). The G+C content of genomic DNA was determined by the thermal denaturation method of Marmur \& Doty (1962), using the equation of Owen \& Hill (1979). The DNA G + C content of this strain is $38 \mathrm{~mol} \%$, a value that is within the range described for the genus Pedobacter (Steyn et al., 1998).

The shape and motility of cells of strain AR $107^{\mathrm{T}}$ from a culture grown for $24 \mathrm{~h}$ in liquid R2A medium were observed under a phase-contrast microscope $(\times 1000)$. Growth at different temperatures $\left(4-40^{\circ} \mathrm{C}\right)$, $\mathrm{pH}$ values $(\mathrm{pH} 3-12)$ and $\mathrm{NaCl}$ concentrations $(0-5 \% \mathrm{NaCl})$ was tested on solid and liquid R2A medium. The isolate was also tested for its ability to grow on MacConkey agar (Difco), nutrient agar and TSA (Difco). Oxidase activity was determined by using a $1 \%$ solution of tetramethyl-p-phenylenediamine (Difco) (Kovács, 1956). Acid and gas production from glucose, lactose and sucrose were determined in Kligler's iron agar (Difco). Catalase activity was tested by picking a young colony and mixing it into a drop of $\mathrm{H}_{2} \mathrm{O}_{2}$. The methyl red and Voges-Proskauer reactions were tested in Clark-Lubs medium (Scharlau). Indole production was determined with Kovács' reagent in $1 \%$ tryptone broth. The Simmons' citrate test was performed (Simmons' citrate agar; Sigma). Medium containing $0.5 \%$ peptone, $0.5 \% \mathrm{NaCl}$ and $0.001 \%$ phenol red was used (Cowan \& Steel, 1974) for the determination of acid production from different carbohydrates. Nitrate reduction was tested for on nitrate broth containing $0 \cdot 2 \% \mathrm{KNO}_{3}$ (Skerman, 1967). Urease activity was studied in Christensen's medium (Christensen, 1946). Hydrolysis of gelatin, starch and DNA was tested on the corresponding agar media (Scharlau). Tween 80 hydrolysis was tested in R2A medium containing $1 \%$ Tween 80 and $0.02 \% \mathrm{CaCl}_{2}$. Casein hydrolysis was tested in $\mathrm{R} 2 \mathrm{~A}$ medium supplemented with $2 \%$ skimmed milk (Difco) (Cowan \& Steel, 1974). The presence of flexirubin-type pigments was examined as described by Bernardet et al. (2002). API 20NE and API ZYM strips (bioMérieux) were inoculated according to the manufacturer's instructions and incubated at $28^{\circ} \mathrm{C}$. An API $50 \mathrm{CH}$ strip (bioMérieux) was inoculated as described by Kersters et al. (1984) and incubated at $28^{\circ} \mathrm{C}$. Antibiotic susceptibilities were determined according to the conventional Kirby-Bauer method (Bauer et al., 1966).
Differential characteristics with respect to other species of Pedobacter are shown in Table 1 (see the species description for further details).

Fatty acid, polar lipid and quinone analyses were carried out by the Identification Service of the Deutsche Sammlung von Mikroorganismen und Zellkulturen (Braunschweig, Germany). Cells were cultured for $24 \mathrm{~h}$ at $28^{\circ} \mathrm{C}$ on TSA medium at pH 7·0 (Miller, 1982; Kämpfer \& Kroppenstedt, 1996). The predominant fatty acids of strain $A R 107^{\mathrm{T}}$ were iso- $\mathrm{C}_{15: 0}$, iso- $\mathrm{C}_{17: 0} 3-\mathrm{OH}$ and summed feature 3 (iso- $\mathrm{C}_{15: 0}$ 2-OH and/or $\mathrm{C}_{16: 1} \omega 7 c$ ) (Table 2). Significant amounts of these fatty acids are characteristic of members of the family Sphingobacteriaceae (Steyn et al., 1998). Like other members of the genus Pedobacter, strain AR $107^{\mathrm{T}}$ contains sphingolipids and MK-7 was the predominant menaquinone system.

As the phenotypic, genotypic and chemotaxonomic features of strain $\mathrm{AR} 107^{\mathrm{T}}$ are similar to those of Pedobacter species, and the phylogenetic results clearly show that it is also closely related to species of this genus, we propose to include it in a novel species, for which the name Pedobacter aquatilis sp. nov. is proposed. As P. aquatilis and the three most recently described species possess traits different from those described for the previously identified Pedobacter species, we also propose an emended description for the genus Pedobacter.

\section{Emended description of Pedobacter Steyn et al. 1998}

The genus description is as given by Steyn et al. (1998) and emended by Vanparys et al. (2005), with the following changes. Colonies on TSA have different pigmentations, from dirty yellow to creamy white or pink. Voges-Proskauer, gelatin hydrolysis and arginine dihydrolase tests are variable. Some strains grow on MacConkey agar. Isolated from soil, activated sludge, fish, glacier water, glacier cryoconite and drinking water. The type species is Pedobacter heparinus.

\section{Description of Pedobacter aquatilis sp. nov.}

Pedobacter aquatilis (a.qua.ti'lis. L. masc. adj. aquatilis aquatic, growing in water).

Gram-negative rods, $0 \cdot 8-1 \times 2-6 \mu \mathrm{m}$ in size, occurring singly, in pairs or in short chains. Non-spore-forming. Cells are non-motile. Colonies on TSA plates are pale pink, round 
Table 1. Differential characteristics of strain $A R 107^{\top}$ and species of the genus Pedobacter

All taxa are positive for catalase, oxidase, phosphatase, $\beta$-galactosidase, aesculin hydrolysis and assimilation of D-glucose, D-mannose and $N$-acetylglucosamine. All strains are negative for reduction of nitrate, indole production, urease activity and assimilation of erythritol, L-sorbose, dulcitol and inositol. Unless otherwise indicated, data for reference species are taken from Vanparys et al. (2005) (P. caeni), Shivaji et al. (2005) (P. himalayensis and P. cryoconitis) and Steyn et al. (1998) (P. heparinus, P. africanus, P. piscium and P. saltans). +, Positive; -, negative; $\mathrm{V}$, variable; $\mathrm{NA}$, data not available.

\begin{tabular}{|c|c|c|c|c|c|c|c|c|}
\hline Characteristic & Strain AR107 ${ }^{\mathrm{T}}$ & P. caeni & P. himalayensis & P. cryoconitis & P. heparinus & P. africanus & P. piscium & P. saltans \\
\hline Habitat & $\begin{array}{c}\text { Drinking } \\
\text { water }\end{array}$ & $\begin{array}{l}\text { Nitrifying } \\
\text { inoculum }\end{array}$ & Glacier water & $\begin{array}{c}\text { Glacier } \\
\text { cryoconite }\end{array}$ & Soil & Soil, sludge & Fish & Soil \\
\hline Colony pigmentation & Pink & $\begin{array}{c}\text { Creamish white } \\
\text { to yellow }\end{array}$ & Pale white & $\begin{array}{l}\text { Creamish } \\
\text { white }\end{array}$ & $\begin{array}{l}\text { Translucent } \\
\text { yellow }\end{array}$ & $\begin{array}{l}\text { Translucent } \\
\text { yellow }\end{array}$ & $\begin{array}{c}\text { Yellow or } \\
\text { creamish white }\end{array}$ & $\begin{array}{l}\text { Light } \\
\text { yellow }\end{array}$ \\
\hline \multicolumn{9}{|l|}{ Temperature for growth $\left({ }^{\circ} \mathrm{C}\right)$} \\
\hline Range & $4-30$ & $\mathrm{NA}$ & $4-25$ & $1-25$ & $5-30$ & $\mathrm{NA}$ & $5-30$ & $\mathrm{NA}$ \\
\hline Maximum & 30 & 37 & 25 & 25 & $37^{*}$ & 37 & $25-30$ & $25-30$ \\
\hline Growth on MacConkey agar & - & NA & + & - & - & - & - & - \\
\hline Gelatin hydrolysis & - & - & + & + & - & $\mathrm{v}$ & - & - \\
\hline Arginine dihydrolase & - & - & + & - & - & - & $\mathrm{NA}$ & - \\
\hline$\beta$-Glucosidase & + & - & + & + & $-1+*$ & $\mathrm{v}$ & $+^{*}$ & + \\
\hline Lipase (C14) & - & - & - & - & $-1-*$ & - & $\mathrm{V}^{*}$ & - \\
\hline Esterase lipase & + & + & $\mathrm{NA}$ & $\mathrm{NA}$ & + & + & + & + \\
\hline Esterase & + & - & $\mathrm{NA}$ & $\mathrm{NA}$ & $-1+*$ & - & $+^{*}$ & - \\
\hline Leucine arylamidase & + & + & $\mathrm{NA}$ & $\mathrm{NA}$ & + & + & + & + \\
\hline Valine arylamidase & + & - & $\mathrm{NA}$ & $\mathrm{NA}$ & $-1-*$ & $\mathrm{v}$ & $+^{*}$ & $\mathrm{v}$ \\
\hline Cystine arylamidase & + & - & $\mathrm{NA}$ & $\mathrm{NA}$ & $-1+*$ & - & $+^{*}$ & - \\
\hline Trypsin & + & - & $\mathrm{NA}$ & $\mathrm{NA}$ & $-1-*$ & - & $t^{*}$ & - \\
\hline$\alpha$-Chymotrypsin & - & - & $\mathrm{NA}$ & $\mathrm{NA}$ & $-1+*$ & - & $t^{*}$ & - \\
\hline Naphthol-AS-BI-phosphohydrolase & + & - & $\mathrm{NA}$ & $\mathrm{NA}$ & $+\dagger$ & $+\dagger$ & $\mathrm{NA}$ & $\mathrm{NA}$ \\
\hline$\alpha$-Galactosidase & - & - & $\mathrm{NA}$ & $\mathrm{NA}$ & $-1+*$ & - & $+^{*}$ & - \\
\hline$\beta$-Glucuronidase & - & - & $\mathrm{NA}$ & $\mathrm{NA}$ & $-1-*$ & - & $\mathrm{V}^{*}$ & $\mathrm{v}$ \\
\hline$\alpha$-Glucosidase & + & - & $\mathrm{NA}$ & $\mathrm{NA}$ & + & + & + & + \\
\hline$N$-Acetyl- $\beta$-glucosaminidase & + & - & $\mathrm{NA}$ & $\mathrm{NA}$ & + & + & + & + \\
\hline$\alpha$-Mannosidase & + & - & $\mathrm{NA}$ & $\mathrm{NA}$ & $-1+*$ & $\mathrm{v}$ & $t^{*}$ & - \\
\hline$\alpha$-Fucosidase & - & - & $\mathrm{NA}$ & $\mathrm{NA}$ & - & - & - & - \\
\hline \multicolumn{9}{|l|}{ Assimilation of: } \\
\hline D-Melezitose & + & - & - & - & - & - & - & - \\
\hline D-Arabinose & - & - & + & - & - & $\mathrm{v}$ & - & $\mathrm{v}$ \\
\hline L-Arabinose & + & + & + & + & + & $\mathrm{v}$ & + & + \\
\hline Ribose & - & - & + & - & - & $\mathrm{v}$ & - & - \\
\hline D-Galactose & + & - & + & + & + & + & $\mathrm{v}$ & + \\
\hline L-Rhamnose & + & - & + & - & + & + & $\mathrm{v}$ & + \\
\hline D-Cellobiose & + & + & + & + & + & + & + & - \\
\hline
\end{tabular}


Table 1. cont.

\begin{tabular}{|c|c|c|c|c|c|c|c|c|}
\hline Characteristic & Strain AR $107^{\mathrm{T}}$ & P. caeni & P. himalayensis & P. cryoconitis & P. heparinus & P. africanus & P. piscium & P. saltans \\
\hline Sucrose & + & + & + & + & + & + & + & $\mathrm{V}$ \\
\hline D-Trehalose & + & + & + & + & + & + & + & $\mathrm{V}$ \\
\hline D-Maltose & + & + & + & + & + & $\mathrm{V}$ & + & + \\
\hline Inulin & - & - & + & + & - & - & - & - \\
\hline Glycogen & - & - & - & + & - & - & - & - \\
\hline Salicin & + & + & + & + & + & $\mathrm{V}$ & + & + \\
\hline Mannitol & - & - & + & - & + & - & - & - \\
\hline Glycerol & - & - & + & - & - & - & - & + \\
\hline D-Xylose & - & - & + & + & + & $\mathrm{V}$ & + & + \\
\hline D-Adonitol & - & - & + & - & + & - & - & + \\
\hline D-Galactose & + & - & + & + & + & + & $\mathrm{V}$ & + \\
\hline D-Fructose & + & - & + & + & + & $\mathrm{V}$ & + & $\mathrm{V}$ \\
\hline D-Sorbitol & - & - & + & - & + & - & - & - \\
\hline Arbutin & + & + & + & + & $\mathrm{V}$ & $\mathrm{V}$ & + & + \\
\hline D-Raffinose & + & + & + & + & - & - & + & $\mathrm{V}$ \\
\hline Starch & + & + & + & + & - & $\mathrm{V}$ & + & - \\
\hline Xylitol & - & + & - & - & - & - & - & - \\
\hline L-Fucose & - & - & + & + & + & $\mathrm{V}$ & - & - \\
\hline \multicolumn{9}{|l|}{ Acid production from: } \\
\hline D-Arabinose & - & NA & - & - & $\mathrm{V}$ & $\mathrm{V}$ & $\mathrm{v}$ & $\mathrm{V}$ \\
\hline D-Glucose & - & NA & - & - & $\mathrm{V} /+^{*}$ & $\mathrm{v}$ & $+^{\star}$ & $\mathrm{V}$ \\
\hline D-Mannose & - & $\mathrm{NA}$ & + & - & - & - & $\mathrm{NA}$ & NA \\
\hline DNA G $+\mathrm{C}$ content $(\mathrm{mol} \%)$ & 38 & $42 \cdot 7$ & 41 & $43 \cdot 4$ & $42-43$ & $43-45$ & $40-43$ & $36-38$ \\
\hline
\end{tabular}

${ }^{\star}$ Data from Takeuchi \& Yokota (1992).

$\dagger$ Data from Vanparys et al. (2005). 
Table 2. Cellular fatty acid composition (\%) of strain $A R 107^{\top}$ and Pedobacter species

Taxa: 1, strain AR $107^{\mathrm{T}}$ (data from this study); 2, P. caeni; 3, P. africanus; 4, P. heparinus (data in columns 2-4 from Vanparys et al., 2005); 5, P. himalayensis; 6, P. cryoconitis (data in columns 5 and 6 from Shivaji et al., 2005); 7, P. piscium; 8, P. saltans (data in columns 7 and 8 from Steyn et al., 1998). - , Not detected; tr, trace $(<1 \cdot 0 \%)$. Summed feature 3 contains iso- $\mathrm{C}_{15: 0} 2-\mathrm{OH}$ and/or $\mathrm{C}_{16: 1} \omega 7 c$.

\begin{tabular}{|c|c|c|c|c|c|c|c|c|}
\hline Fatty acid & 1 & 2 & 3 & 4 & 5 & 6 & 7 & 8 \\
\hline $\mathrm{C}_{14: 0}$ & $1 \cdot 0$ & $2 \cdot 5$ & $1 \cdot 2$ & $1 \cdot 1$ & $1 \cdot 0$ & $1 \cdot 0$ & $1 \cdot 3$ & $\operatorname{tr}$ \\
\hline $\mathrm{C}_{15: 0}$ & $1 \cdot 6$ & - & - & - & - & - & - & $1 \cdot 4$ \\
\hline $\mathrm{C}_{15: 1} \omega 6 c$ & $2 \cdot 1$ & - & $\operatorname{tr}$ & - & - & - & - & $1 \cdot 4$ \\
\hline iso- $\mathrm{C}_{15: 0}$ & $28 \cdot 9$ & $21 \cdot 3$ & $33 \cdot 3$ & $27 \cdot 9$ & $33 \cdot 0$ & $15 \cdot 0$ & $26 \cdot 2$ & $31 \cdot 4$ \\
\hline anteiso- $\mathrm{C}_{15: 0}$ & $\operatorname{tr}$ & $\operatorname{tr}$ & $1 \cdot 0$ & $\operatorname{tr}$ & - & - & $2 \cdot 6$ & $2 \cdot 9$ \\
\hline $\mathrm{C}_{15: 0} 2-\mathrm{OH}$ & $\operatorname{tr}$ & $\operatorname{tr}$ & $\operatorname{tr}$ & $\operatorname{tr}$ & - & - & - & - \\
\hline iso- $\mathrm{C}_{15: 0} 3-\mathrm{OH}$ & $2 \cdot 7$ & $3 \cdot 3$ & $2 \cdot 1$ & $3 \cdot 6$ & $1 \cdot 5$ & $1 \cdot 9$ & $2 \cdot 5$ & $2 \cdot 8$ \\
\hline$C_{16: 0}$ & $1 \cdot 9$ & $3 \cdot 0$ & $2 \cdot 2$ & $2 \cdot 2$ & $7 \cdot 3$ & $9 \cdot 1$ & $3 \cdot 3$ & $4 \cdot 0$ \\
\hline $\mathrm{C}_{16: 1} \omega 5 c$ & $3 \cdot 2$ & $2 \cdot 5$ & $1 \cdot 3$ & $1 \cdot 9$ & - & - & $3 \cdot 5$ & $\operatorname{tr}$ \\
\hline $\mathrm{C}_{16: 0} 3-\mathrm{OH}$ & $3 \cdot 5$ & $2 \cdot 8$ & $1 \cdot 6$ & $2 \cdot 2$ & - & - & $4 \cdot 5$ & $\operatorname{tr}$ \\
\hline iso- $\mathrm{C}_{17: 1} \omega 9 c$ & $2 \cdot 6$ & $2 \cdot 2$ & $6 \cdot 5$ & $6 \cdot 4$ & $4 \cdot 0$ & $8 \cdot 6$ & $1 \cdot 6$ & $6 \cdot 6$ \\
\hline anteiso- $\mathrm{C}_{17: 1} \omega 9 c$ & - & $\operatorname{tr}$ & - & - & - & - & $1 \cdot 2$ & - \\
\hline $\mathrm{C}_{17: 0} 2-\mathrm{OH}$ & $\operatorname{tr}$ & $1 \cdot 3$ & $\operatorname{tr}$ & $2 \cdot 7$ & - & - & - & - \\
\hline iso- $\mathrm{C}_{17: 0} 3-\mathrm{OH}$ & $13 \cdot 6$ & $12 \cdot 1$ & $16 \cdot 1$ & $14 \cdot 0$ & $6 \cdot 0$ & $4 \cdot 2$ & $9 \cdot 2$ & $12 \cdot 7$ \\
\hline Summed feature 3 & $30 \cdot 7$ & $39 \cdot 9$ & $26 \cdot 5$ & $31 \cdot 7$ & 22 & 29 & $42 \cdot 1$ & $28 \cdot 5$ \\
\hline
\end{tabular}

and convex and 1-2 $\mathrm{mm}$ in diameter after $48 \mathrm{~h}$ at $28^{\circ} \mathrm{C}$. Pigments do not give the typical flexirubin reaction with $20 \% \mathrm{KOH}$. Strictly aerobic. Does not grow in the presence of $\geqslant 2 \% \mathrm{NaCl}$. Growth occurs at temperatures between 4 and $30{ }^{\circ} \mathrm{C}$ (optimal temperature $25-28^{\circ} \mathrm{C}$ ) and at $\mathrm{pH} 5-9$ (optimal pH 6-7). Good growth occurs in R2A and TSA media but not on MacConkey agar medium. Positive for oxidase and catalase activities. Negative for urease activity. Negative for indole and in the methyl red and VogesProskauer tests. Does not produce $\mathrm{H}_{2} \mathrm{~S}$ from thiosulfate. Starch, aesculin and Tween 80 are hydrolysed but casein, DNA and gelatin are not. Negative result in the Simmons' citrate test. Nitrate is not reduced. Acid is not produced oxidatively from D-galactose, D-mannose, D-glucose, $\mathrm{D}$-arabinose, fructose or D-maltose. Negative for glucose fermentation. L-Arabinose, D-galactose, D-mannose, D-glucose, D-fructose, L-rhamnose, methyl $\alpha$-D-mannopyranoside, methyl $\alpha$-D-glucopyranoside, $N$-acetylglucosamine, amygdalin, arbutin, salicin, D-cellobiose, D-maltose, D-lactose, D-melibiose, sucrose, D-trehalose, D-melezitose, D-raffinose, starch, gentiobiose and D-turanose are used as carbon sources. Glycerol, erythritol, D-arabinose, D-ribose, $\mathrm{D}$-xylose, L-xylose, D-adonitol, methyl $\beta$-D-xylopyranoside, L-sorbose, dulcitol, inositol, D-mannitol, D-sorbitol, inulin, glycogen, xylitol, D-lyxose, D-tagatose, D-fucose, L-fucose, D-arabitol, L-arabitol, potassium gluconate, potassium 2-ketogluconate, potassium 5-ketogluconate, capric acid, adipic acid, malate, trisodium citrate and phenylacetic acid are not used as carbon sources. Alkaline and acid phosphatase, esterase (C4), esterase lipase (C8), leucine arylamidase, valine arylamidase, cystine arylamidase, trypsin, naphthol-AS-BI-phosphohydrolase, $\beta$-galactosidase, $\alpha$-glucosidase, $\beta$-glucosidase, $N$-acetyl- $\beta$-glucosaminidase and $\alpha$-mannosidase are present. Arginine dihydrolase, lipase (C14), $\alpha$-chymotrypsin, $\alpha$-galactosidase, $\beta$-glucuronidase and $\alpha$-fucosidase are not present. Resistant to the following antibiotics ( $\mu \mathrm{g}$ per disc unless otherwise indicated): novobiocin (30), ampicillin (10), neomycin (10), nalidixic acid (30), streptomycin (10) bacitracin (10 U), penicillin (10 U), kanamycin (30), cefazolin (30) and gentamicin (10). Shows an intermediate reaction to the following antibiotics ( $\mu$ g per disc): chloramphenicol (30), tetracycline (30), erythromycin (15) and rifampicin (30). The fatty acid composition is shown in Table 2. Sphingolipids are present. MK-7 is the major respiratory quinone. The DNA G $+\mathrm{C}$ content is $38 \mathrm{~mol} \%$.

The type strain, strain $\mathrm{AR} 107^{\mathrm{T}}\left(=\mathrm{CCM} 7347^{\mathrm{T}}=\mathrm{CECT}\right.$ $7114^{\mathrm{T}}=\mathrm{JCM} 13454^{\mathrm{T}}$ ), was isolated from drinking water.

\section{Acknowledgements}

V. G. was supported by a fellowship from the Spanish Ministerio de Educación y Ciencia. This work was supported by grants from the Quality of Life and Management of Living Resources Programme of the European Commission (QLK3-CT-2002-01972), the Spanish Ministerio de Ciencia y Tecnología (BMC2003-01344) and from the Junta de Andalucía.

\section{References}

Bauer, A. W., Kirby, W. M. M., Sherris, J. C. \& Turck, M. (1966). Antibiotic susceptibility testing by a standardized single disk method. Am J Clin Pathol 45, 493-496.

Bernardet, J.-F., Nakagawa, Y. \& Holmes, B. (2002). Proposed minimal standards for describing new taxa of the family 
Flavobacteriaceae and emended description of the family. Int J Syst Evol Microbiol 52, 1049-1070.

Christensen, W. B. (1946). Urea decomposition as a means of differentiating Proteus and paracolon cultures from each other and from Salmonella and Shigella types. J Bacteriol 52, 461-466.

Cowan, S. T. \& Steel, K. J. (1974). Manual for the Identification of Medical Bacteria. Cambridge: Cambridge University Press.

Felsenstein, J. (1991). Evolutionary trees from DNA sequences: a maximum likelihood approach. J Mol Evol 17, 368-376.

Kämpfer, P. \& Kroppenstedt, R. M. (1996). Numerical analysis of fatty acid patterns of coryneform bacteria and related taxa. Can J Microbiol 42, 989-1005.

Kersters, K., Hinz, K.-H., Hertle, A., Segers, P., Lievens, A., Siegmann, O. \& De Ley, J. (1984). Bordetella avium sp. nov., isolated from the respiratory tracts of turkeys and other birds. Int J Syst Bacteriol 34, 56-70.

Kluge, A. G. \& Farris, F. S. (1969). Quantitative phyletics and the evolution of anurans. Syst Zool 18, 1-32.

Kovács, N. (1956). Identification of Pseudomonas pyocyanea by the oxidase reaction. Nature 178, 703-704.

Ludwig, W., Strunk, O., Westram, R. \& 29 other authors (2004). ARB: a software environment for sequence data. Nucleic Acids Res 32, 1363-1371.

Margesin, R., Spröer, C., Schumann, P. \& Schinner, F. (2003). Pedobacter cryoconitis sp. nov., a facultative psychrophile from alpine glacier cryoconite. Int J Syst Evol Microbiol 53, 1291-1296.

Marmur, J. (1961). A procedure for the isolation of deoxyribonucleic acid from micro-organisms. J Mol Biol 3, 208-218.

Marmur, J. \& Doty, P. (1962). Determination of the base composition of deoxyribonucleic acid from its thermal denaturation temperature. J Mol Biol 5, 109-118.

Mellado, E., Moore, E. R. B., Nieto, J. J. \& Ventosa, A. (1995). Phylogenetic inferences and taxonomic consequences of $16 \mathrm{~S}$ ribosomal DNA sequence comparison of Chromohalobacter marismortui, Volcaniella eurihalina and Deleya salina, and reclassification of $V$. eurihalina as Halomonas eurihalina comb. nov. Int J Syst Bacteriol 45, $712-716$.
Miller, L. T. (1982). A single derivatization method for bacterial fatty acid methyl esters including hydroxy acids. J Clin Microbiol 16, 584-586.

Owen, R. J. \& Hill, L. R. (1979). The estimation and base compositions, base pairing and genome size of bacterial deoxyribonucleic acids. In Identification Methods for Microbiologists, 2nd edn, pp. 217-296. Edited by F. A. Skinner \& D. W. Lovelock. London: Academic Press.

Reasoner, D. J. \& Geldreich, E. E. (1985). A new medium for enumeration and subculture of bacteria from potable water. Appl Environ Microbiol 49, 1-7.

Saitou, N. \& Nei, M. (1987). The neighbor-joining method: a new method for reconstructing phylogenetic trees. Mol Biol Evol 4, 406-425.

Shivaji, S., Chaturvedi, P., Reddy, G. S. N. \& Suresh, K. (2005). Pedobacter himalayensis sp. nov., from the Hamta glacier located in the Himalayan mountain ranges of India. Int J Syst Evol Microbiol 55, 1083-1088.

Skerman, V. B. D. (1967). A Guide to the Identification of the Genera of Bacteria, 2nd edn. Baltimore: Williams \& Wilkins.

Stackebrandt, E. \& Goebel, B. M. (1994). Taxonomic note: a place for DNA-DNA reassociation and 16S rRNA sequence analysis in the present species definition in bacteriology. Int $J$ Syst Bacteriol 44, 846-849.

Steyn, P. L., Segers, P., Vancanneyt, M., Sandra, P., Kersters, K. \& Joubert, J. J. (1998). Classification of heparinolytic bacteria into a new genus, Pedobacter, comprising four species: Pedobacter heparinus comb. nov., Pedobacter piscium comb. nov., Pedobacter africanus sp. nov. and Pedobacter saltans sp. nov. Proposal of the family Sphingobacteriaceae fam. nov. Int J Syst Bacteriol 48, 165-177.

Takeuchi, M. \& Yokota, A. (1992). Proposals of Sphingobacterium faecium sp. nov., Sphingobacterium piscium sp. nov., Sphingobacterium heparinum comb. nov. and two genospecies of the genus Sphingobacterium, and synonymy of Flavobacterium yabuuchiae and Sphingobacterium spiritivorum. J Gen Appl Microbiol 38, 465-482.

Vanparys, B., Heylen, K., Lebbe, L. \& De Vos, P. (2005). Pedobacter caeni sp. nov., a novel species isolated from a nitrifying inoculum. Int J Syst Evol Microbiol 55, 1315-1318. 